Volume 8

$5-1-2014$

\title{
Justice and Time at the Khmer Rouge Tribunal: In Memory of Vann Nath, Painter and S-21 Survivor
}

\author{
Alexander Laban Hinton \\ Center for the Study of Genocide and Human Rights, Department of Anthropology and Division of Global \\ Affairs, Rutgers University, Newark, NJ
}

Follow this and additional works at: https://digitalcommons.usf.edu/gsp

\section{Recommended Citation}

Hinton, Alexander Laban (2014) "Justice and Time at the Khmer Rouge Tribunal: In Memory of Vann Nath, Painter and S-21 Survivor," Genocide Studies and Prevention: An International Journal: Vol. 8: Iss. 2: 7-17. DOI:

http://dx.doi.org/10.5038/1911-9933.8.2.3

Available at: https://digitalcommons.usf.edu/gsp/vol8/iss2/5

This Articles is brought to you for free and open access by the Open Access Journals at Digital Commons @ University of South Florida. It has been accepted for inclusion in Genocide Studies and Prevention: An International Journal by an authorized editor of Digital Commons @ University of South Florida. For more information, please contact digitalcommons@usf.edu. 


\title{
Justice and Time at the Khmer Rouge Tribunal: In Memory of Vann Nath, Painter and S-21 Survivor
}

\author{
Alexander Laban Hinton ${ }^{1}$ \\ Center for the Study of Genocide and Human Rights \\ Department of Anthropology and Division of Global Affairs \\ Rutgers University, Newark, NJ \\ http://www.ncas.rutgers.edu/cghr
}

\begin{abstract}
"The historical truth will never be found in this courtroom or any courtroom for that matter because courts are not designed for the historical truth."

Michael Karnavas, International Co-Defense Lawyer for Ieng Sary²

"Is this court trying to bury history? And why?"

Michiel Pestman, International Co-Defense Lawyer for Nuon Chea ${ }^{3}$

"I believe there will be justice. A person harvests what he has sown. According to the Buddhist religion, good actions produce good results, bad actions produce bad results."

Vann Nath, survivor of S-21 prison ${ }^{4}$

Abstract: This essay explores the interrelationship of justice and time at the Extraordinary Chambers in the Courts of Cambodia [ECCC hyperlink: http://www.eccc.gov.kh/en] (ECCC, or "Khmer Rouge Tribunal"). In doing so, it follows the trial participation of the late Vann Nath, a survivor of S-21, a torture and detention center operated by the Khmer Rouge. From April 15, 1975 to January 6, 1979, this Maoist-inspired group of revolutionary implemented policies resulting in the death of up to two million of Cambodia's eight million inhabitants, almost a quarter of the population. This essay argue that, even as they seek to help post-conflict societies like Cambodia "move forward through justice" (as the ECCC slogan goes), transitional justice mechanisms like the ECCC are premised on a set of temporal assumptions that are part of a larger transitional justice imaginary. Scholars and practitioners need to attend to such assumptions as well as the sorts of "vernacular time," or local conceptions of temporality that also mediate the understanding and responses of people like Vann Nath.
\end{abstract}

Keywords: genocide, transitional justice, tribunals, violence, Cambodia, Khmer Rouge, reconciliation, justice, Extraordinary Chambers in the Courts of Cambodia, Khmer Rouge Tribunal

\section{Vann Nath at the Khmer Rouge Tribunal}

Does justice for mass murder have meaning 32 years after the fact? This question was a hot topic of discussion in Cambodia in June 2011, when I attended the initial hearings that launched the trial of the four surviving, most senior leaders of the Khmer Rouge, which finally got underway at the Extraordinary Chambers in the Courts of Cambodia (ECCC). At this United Nations (UN)-backed international hybrid court, more commonly known as the Khmer Rouge Tribunal (KRT), the scales of justice appeared to be set before an hourglass, one that was quickly running out of sand.

After more than twenty-five years of delay, it took roughly three years after the June 2006 launch of the court for the first trial to begin. Only in February 2012 was the verdict finalized after the Supreme Court issued its decision on appeals, sentencing the accused, Duch, the former commandant of the regime's central prison and interrogation center (S-21), to life imprisonment. And that was supposed to be the quick case, more or less a "slam dunk" of justice since the accused admitted his guilt and cooperated throughout the trial.

Meanwhile, the second case, involving the four most senior, surviving leaders of the Khmer Rouge -- a group of Maoist-inspired revolutionaries who enacted policies leading to the deaths of almost two million of the country's eight million inhabitants from April 17, 1975 to January 6, 1979 -- had only more recently gotten underway, now more than thirty years after they were overthrown by a Vietnamese-backed army.

On June 27, 2011, the first morning of the initial hearing, I sat with 66 year-old artist Vann Nath, one of a handful of survivors of S-21, the Khmer Rouge security center where over 12,000 inmates perished, many after being interrogated and tortured. We were positioned just yards away from the defendants: Brother 
Number Two, Nuon Chea (age 85); Pol Pot's brother-in-law and Foreign Affairs Minister, Ieng Sary (age 86); Ieng Sary's wife and Minister of Social Affairs, Ieng Thirith (age 79); and Head of State, Khieu Samphan (age 80). There was also an unspoken absence, as their leader, Pol Pot ("Brother Number One"), and other highranking officials such as General Ta Mok and Minister of Defense, Son Sen, have passed away or been killed.

Too much time had passed. And, by the look of things on that morning, it appeared questionable that the octogenarian defendants would all be able to participate fully or even live long enough to see the conclusion of the trial, which could last for several years.

As we gazed at the enfeebled defendants, who suffer from various ailments and at times needed help to stand, it was hard to imagine them overseeing one of the most radical experiments of social engineering in human history. Upon taking power after a brutal civil war that had led to hundreds of thousands of deaths, devastated the economy, and resulted in massive population displacements, the Khmer Rouge set out to build a new revolutionary society, one that would be purified of, as they put it, the "corrupting" influence of capitalism, feudalism, and neo-imperialism.

Money, markets, and traditional community life were replaced by cooperatives where people worked day and night in a constant state of fear and terror. Freedom of speech, movement, and assembly were severely curtailed. Buddhism was banned. Family members were forced to live and work apart for long hours and often on starvation rations. And then there were the purges and mass executions. In just 3 years, 8 months, and 20 days, the Khmer Rouge enacted policies leading to the deaths of almost a quarter of the population.

$* * *$

Roughly two years earlier during Duch's trial, Vann Nath had told the story of how he became swept up in the violence. It was a story that he had told before, to me and others in interviews and in a memoir, but, as he told the court that day, he was happy to do so because he wanted his testimony both to serve as a "mirror" upon which the younger generations could reflect and as a way to attain "justice for [the dead]," a justice that would be "seen by everybody." On the first day of Duch's trial, Vann Nath had told journalists, "I couldn't sleep last night. I was dreaming about my time at S-21."

Vann Nath told the story of how he and his family and the rest of the population of Battambang City had been relocated to the countryside, where they, like Cambodians throughout the country, were forced to perform agricultural labor for long hours on increasingly meager rations. In the Khmer Rouge imagination, the creation of a mass agrarian work force would catalyze a "super great leap forward," one that would surpass China and Vietnam. The plan failed miserably and the population suffered the consequences both through diminished rations and from purges the Khmer Rouge leadership launched to track down the "traitors" who were subverting the revolution -- for it was inconceivable that the "all-knowing" Party Center had a deficient party line.

On December 30, 1977, Vann Nath was swept up in the purges, which were well underway, with executions taking place on the cooperative, district, provincial, and national levels. Upon his arrest, Vann Nath was taken to a pagoda that had been converted into a detention center, where he was accused of being a traitor and tortured by electric shock.

Eventually Vann Nath was trucked to S-21, located in Phnom Penh. He said that after arriving at S-21, he lost all hope upon seeing how the guards "degraded us. It's indescribable, the way they treated us, the prisoners. Sometimes... while we were asleep they suddenly woke us up and if we could not sit up on time then they used their rubber [tire] thongs to kick our heads."

Vann Nath was shackled in a communal cell, where the prisoners subsisted on a few spoonfuls of rice gruel at each meal. They rapidly began to weaken, which made them more susceptible to rashes and ailments. Due to infrequent bathing, they began to smell. Over time, they barely looked human. The starving prisoners would eat grasshoppers or other insects if they could catch them, a difficult task since they were closely watched and would be beaten if they moved about or spoke to others. The prisoners "didn't care" if a companion died because "we were like animals." Vann Nath thought only of thirst and hunger, a deprivation that was so extreme that he recalled thinking "that even eating ... human flesh would be a good meal." Meanwhile, the guards kicked and beat them without hesitation. Many inmates were interrogated and tortured; almost everyone was executed soon after arrival.

Vann Nath survived because he could paint. In 1980, he was shown an execution list that included his name, crossed out in red ink with the annotation "keep for use." While conditions were much better in 


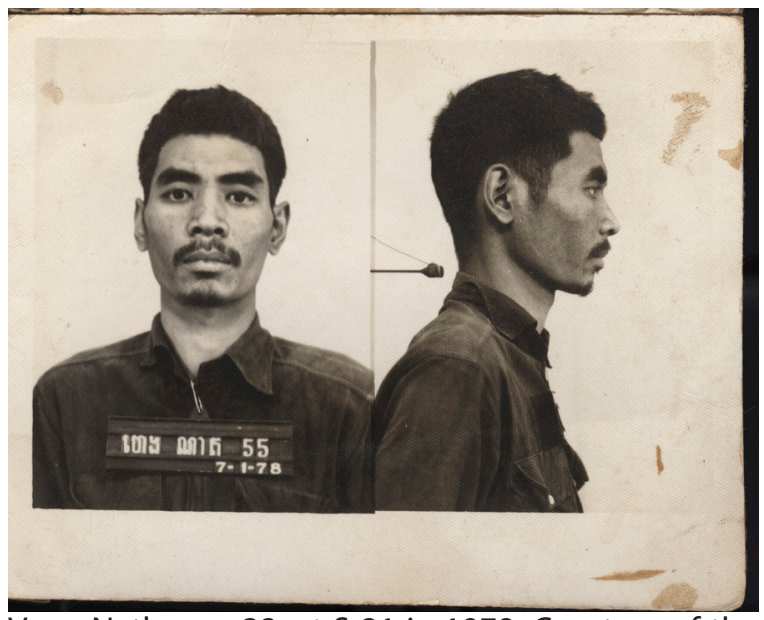

Vann Nath, age 32, at S-21 in 1978. Courtesy of the Documentation Center of Cambodia. [http://www.dccam.org] the small artisan workshop where he began to work, Vann Nath frequently heard the screams of prisoners being tortured (one "got used to it") and caught glimpses of the suffering and violence that took place at S-21, such as prisoners shackled in cells and a man strung to a pole like an animal.

After the fall of the Khmer Rouge, Vann Nath returned to work at S-21, where a genocide museum was being built. His contribution was to paint pictures about what he had seen or heard or what other former prisoners related to him. During his testimony, his paintings were displayed, which included scenes depicting a prisoner being tortured by having his fingernails pulled out; waterboarding; and a baby being taken from a mother. These paintings are among the most powerful and iconic images at the museum that has been constructed at S-21.

As Vann Nath and I sat together at the initial hearing before the proceedings began, I asked him why he had come to the court. "For justice," he told me. "And to see their faces." When Nuon Chea, wearing a black and white ski cap and sunglasses, complained that he was "not happy" with the proceedings, Vann Nath just shook his head, perhaps recalling how he was imprisoned by the Khmer Rouge without rights, counsel, or due process.

As Vann Nath departed after the first morning session, he was surrounded by a large flock of journalists, eager to hear the impressions from this de facto spokesperson for Khmer Rouge victims.

This was the last court session Vann Nath attended. He died, after suffering from kidney disease for many years, on September 5, 2011.

$* * *$

Vann Nath's death brought the issue of justice and time into stark relief. An obituary by civil society leader Youk Chhang stated that Vann Nath's passing illustrated "the high cost that the simple passage of time

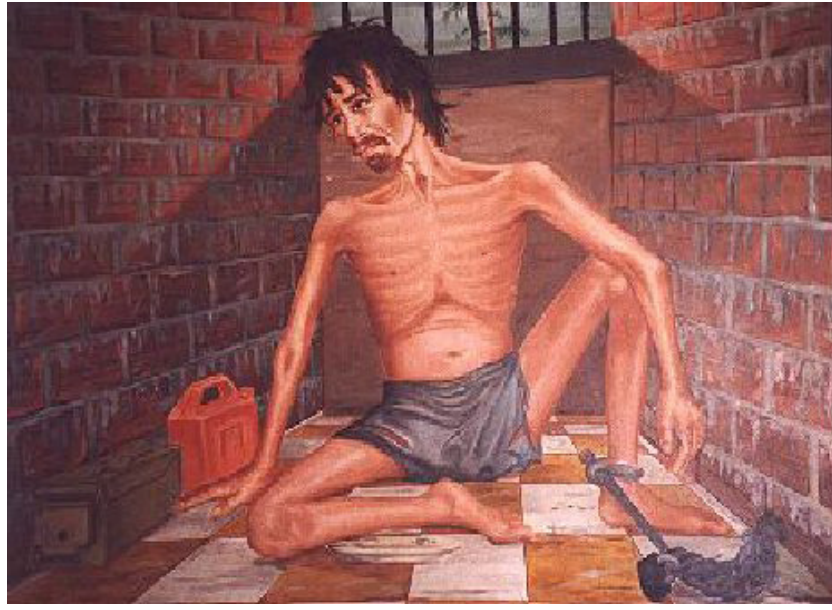

S-21 Prisoner in Cell (Tuol Sleng Museum of Genocide Crimes), painting by Vann Nath. Photograph by author.

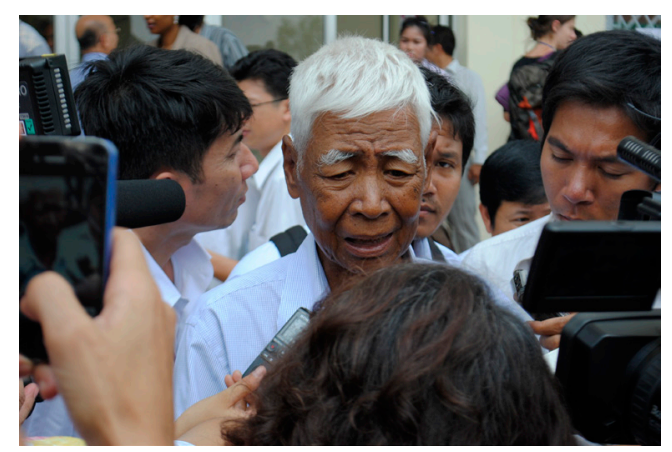

Vann Nath speaking to journalist at the ECCC in 2011. Photo courtesy of the Documentation Center of Cambodia. 
can inflect on the pursuit of justice. Sadly, this tragedy repeats itself silently throughout Cambodia, as each day victims of the Khmer Rouge pass away without having been provided any measure of justice."10 This sentiment was echoed by others, including civil party lawyers, donors, monitoring groups, and survivors, who underscored the importance of moving the proceedings forward without further delay. ${ }^{11}$

After the weeklong initial hearings in June 2011, the case had stalled once again due to a host of complications ranging from a sudden surge in civil party applications to numerous appeals by the four teams of defense lawyers. Meanwhile, it became increasingly doubtful that the aging leaders would all be able to participate fully or even live long enough to see the trial, which could last for several years, conclude.

On October 24, 2011, Ieng Sary's lawyers notified the court that Ieng Sary, who was having trouble focusing and having to relieve himself frequently, would not testify during the proceedings. ${ }^{12} \mathrm{He}$ would die in 2013 before the trial ended. On November 17, 2011, the Trial Chamber found that Ieng Thirith suffers from progressive dementia and was not fit to stand trial. They ordered her release, a decision that once again highlighted the urgency of moving forward with the trial even if it was reversed on appeal on December 13, $2011 .{ }^{13}$ Nuon Chea and Khieu Samphan also complain of ailments, with the latter having suffered a stroke in 2007.

In response to such concerns, the Trial Chamber decided to split the complicated case into parts, the first of which focuses on population movements and crimes against humanity. This was done "in the interests of justice" so that a shorter initial verdict could be rendered, one that would thereby safeguard "the fundamental interest of victims in achieving meaningful and timely justice, and the right of all Accused in Case 002 to an expeditious trial." ${ }^{14}$ To this end, the evidentiary proceedings began on November 21, 2011. Closing arguments would finally be held in October 2013 with a judgment expected in 2014.

\section{Juridical Time}

Time. It is a central motif at the ECCC. If, outside of the court, the KRT has been criticized for its glacial pace, the notion of time also figures prominently in the proceedings themselves. Here, time is directly bound up with fair trial rights, as the importance of upholding the due process rights of the defendants sometimes come into tension with the concerns of the civil parties. In this tribunal, civil parties have procedural rights almost on par with those of the prosecution and defense, including the right to see the accused tried in a timely fashion. Even so, civil party lawyers frequently complain that their clients need additional time to speak in court or that they need more time to cross-examine witnesses. Meanwhile, in the first trial, a monitoring group timed each session down the minute, noting how long the court spent in session on given matters. Here the concern is trial management, as an efficient court presumably operates in a timely manner.

Time, however, constitutes a much bigger backdrop at the ECCC and is directly linked to the ways in which truth and knowledge are produced in the court. One of the most obvious illustrations of this point is temporal jurisdiction. The ECCC is authorized to examine mass human rights violations that took place while the Khmer Rouge were in power - not before and not after. As opposed to seeking a deeply historicized understanding of the genocide, the court provides a temporally limited one.

This was evident in the first case, the trial of Duch, who ran S-21 while Vann Nath was imprisoned there. The judges did explore Duch's work at M-13, a detention center Duch operated during the civil war and where he developed some of the torture techniques he would later employ at S-21. There was brief mention of the complex histories that enabled the Khmer Rouge to rise to power, including the Vietnam War and the U.S. carpet-bombing of Cambodia, but this information was deemed relevant only insofar as it bore upon establishing the guilt or innocence of the accused. Indeed, the trial verdict devotes a mere two pages to the discussion of the historical background of the genocide.

Nuon Chea's defense team focused on this issue as part of a larger strategy of challenging the integrity of the court. On the first morning of the initial hearing, Nuon Chea's international co-defense lawyer, Michiel Pestman, rose to explain why Nuon Chea was "not happy with this hearing," arguing that "the proceedings should be terminated" due to investigative failures, political interference, lack of transparency, judicial incompetence, and temporal bias. ${ }^{15}$

In rapid order, Pestman picked up on a series of controversies at the court, including accusations the Cambodian judges were controlled by the government, the failure of the Office of Co-Investigating Judges to properly investigate Cases 003 and 004, and the subsequent resignation of the international co-investigating judge, and the unwillingness of current Cambodian government officials who were themselves former Khmer Rouge to be interviewed. 
"A trial is like building a house," Pestman explained. "It needs solid foundations, solid judicial investigation. Without a proper foundation, the trial will sooner or later collapse."16 To avoid creating a "show trial" like the 1979 People's Revolutionary Tribunal (PRT) that was "completely orchestrated and controlled by the Vietnamese," Pestman continued, the court needed to "start showing its teeth [...] It is time for transparency, not for sealed envelopes." 17

Time was a central backdrop of Pestman's comments. "Why," he asked, "were the terrible American bombings of Cambodia ... and their lasting impact ... on the people in this country [not investigated]? And why not the dubious role played by Vietnam, the Vietnamese in this country, in Cambodia, before, during and after the Khmer Rouge years. Is this Court trying to bury history? And why?" ${ }^{18}$ Cambodians deserved "a fair trial, a proper trial aimed at establishing the truth and not simply at rubber stamping history books written in Vietnam or in America."19

Pestman's remarks played upon a long-standing debate about what the function of a trial should be. On the one hand a large group of people, ranging from lawyers to diplomats, have argued that such legal proceedings have an important expressive component, a claim echoed in proclamations that such transitional justice mechanisms bring a host of positive results, ranging from healing to reconciliation to revealing "the truth." ${ }^{20}$ The Duch trial, for example, did reveal new things about the operation of S-21 but, by focusing on the years of Khmer Rouge rule in Cambodia, the case ultimately produced a "truth" bleached of historical process and an understanding of the factors that enabled the Khmer Rouge to rise to power.

This was precisely the point Pestman sought to make as part of his larger strategy of calling into question the legitimacy of the court. For if one key objective of a tribunal is to reveal the truth that has been hidden by the politics of memory, then why not explore the structural and historical roots of the genocide and the ways in which it is linked to geopolitics? Indeed, the 1999 "Group of Experts" directly invoked this truth-seeking function of the court, expressing the hope that "the United Nations and international community can assist the Cambodian people in establishing the truth about this period and bringing those responsible to justice. Only in this way can this tragedy be brought to a full and final conclusion."21 The reason for this historical elision, Pestman directly implied, was politics.

Due to the Cold War and Cambodia's attempt to find peace in the late 1990s, a trial only became a reality almost thirty years after the genocide had ended..$^{22}$ The agreement to form the ECCC, which took years to broker, included a limited temporal jurisdiction ("17 April 1975 to 6 January 1979") that would satisfy the United States and China, superpowers implicated in the origins, dynamics, and aftermaths of the conflict, and a personal jurisdiction ("senior leaders" and those "most responsible") acceptable to Cambodian officials who wanted to avoid an expanding series of investigations that could imperil peace or even implicate current leaders, many of whom are former Khmer Rouge.

Besides eliding sociohistorical dynamics linked to the rise of the Khmer Rouge, like the Vietnam War and the U.S. bombing of the Cambodian countryside, this temporal jurisdiction erases other key events, such as the fact that, after being deposed, the Khmer Rouge were rearmed by the U.S., China, and other powers due to geopolitics. Indeed, the Khmer Rouge were even given Cambodia's seat at the UN. It was only after the 1993 UN elections in Cambodia that many foreign government officials began to speak of the mass violence committed by the Khmer Rouge - as opposed to using euphemisms (for example, "the unfortunate events of the past") as they had often done during the Cold War. Such events are too often omitted in juridical time, which prefers discrete intervals (the time and place of criminality), efficiency and parsimony (in terms of juridical process), and progress (toward a verdict with its attendant qualities, closure and evidentiary truth).

$* * *$

Counterposed to those who argue for the expressive importance of tribunals are those who foreground legalism. This position was directly laid out in Hannah Arendt's Eichmann in Jerusalem, which argues that a court is first and foremost about the law. If a trial reveals something about the past, then that is fine. But a trial is ultimately about legal justice.

At the initial hearing, this position was staked out by Ieng Sary's defense team. Responding to civil party lawyer Moch Sovannary, who had argued on the first day that the "victims need to understand the truth, the truth that they have been long waiting for, so that they can really move on with life,"23 Ieng Sary's international co-lawyer, Michael Karnavas, stated simply that "the historical truth will never be found in this courtroom or any courtroom for that matter because courts are not designed for the historical truth." Because 
of the temporal jurisdiction of the court, Karvanas noted, "the whole picture, the whole truth will never be revealed."24

Instead, Karnavas would argue repeatedly, the court needed to focus on the law. During arguments, Karnavas noted that he was "a fundamental believer in the power of the law. And the law has to be applied whether we like it or not. It is not a technicality. It is not something that we can just ignore when it's convenient or when difficult decisions need to be made." ${ }^{25}$ Later, during the press conference that followed the initial hearing, Karnavas explained that his team had made numerous submissions and legal challenges in the hope that the trials would constitute a "civics lesson" on judicial procedure, one that, after the case had ended, would demonstrate how the Cambodian people should expect a court to work and thereby "contribute to the betterment of Cambodia's future court system."26

During the initial hearings, the Ieng Sary defense team's challenges related directly to the issue of time and justice. First, Karnavas and his Cambodian co-counsel, Ang Udom, argued that Ieng Sary could not be tried since the Peoples Revolutionary Tribunal had already convicted him in 1979. To do so would violate the international legal principle of double-jeopardy (ne bis in idem).

Second, Karnavas and Ang Udom argued that, because Ieng Sary had been granted an amnesty and pardon in 1996, one that was critical in leading to the demise of the Khmer Rouge, who were still waging war in the Cambodian countryside, he was immune from prosecution. And, finally, Ieng Sary's defense lawyers argued that the statute of limitations had run out on their client's crimes and that to ex post facto apply international human rights law to the situation in 1979 would violate his fair trial rights.

These issues raised fundamental questions about juridical time, ones with which courts in other countries have grappled. Are some crimes so heinous that they transcend temporal limits? Relatedly, is it possible to try someone for crimes that are viewed as universal even if they were not formally codified at the time? And can an amnesty given to promote peace be nullified?

Running in the background of these questions were other issues about Cambodian history itself. Why wasn't an international tribunal held immediately after the Khmer Rouge were deposed? The answer, of course, was largely tied to Cold War politics. Why did the Khmer Rouge remain a viable fighting force until the late 1990s? This was partly due to geopolitical machinations that led the U.S., China, and others to support the Khmer Rouge for many years after they had fallen from power. And why was the Cambodian judiciary so incapacitated until the 1990s? Geopolitics, social instability, and international sanctions were among the reasons.

$* * *$

If Karnavas stressed legal process, fair trial rights, and the technicalities of law, civil party lawyers did not just support the prosecution's claims that the arguments of the defense teams were legally untenable, instead asserting that their clients also had fair trial rights, including the right to justice, truth, and reparation. ${ }^{27}$ For victims of mass human rights violations, international civil party co-lawyer Silke Studinsky argued on the second day of the initial hearing, effective remedy meant "fair, effective and prompt access to justice" as well as "prosecution and punishment." ${ }^{28}$ The victims had a right to truth, including "obtaining adequate answers to the important questions - why crimes happened and why they happened to them and their families."29 A pardon or amnesty clearly denied the victims such access to the truth and was "an affront to the pain, suffering and damages done" to the victims. ${ }^{30}$

The day before, Studinsky's international civil party lawyer colleague, Martine Jacquin, had framed these issues more broadly, asking "Can justice heal or manage the suffering - or mitigate the suffering of victims?" Answering her rhetorical question, Jacquin stated, "Justice can only restore whatever harm is reparable and whatever injury for which the victims can claim compensation. But justice cannot restore that which is beyond reparations, the physical and psychological wounds and scars that [are] borne by the victims for an entire lifetime."31 "But," she continued, "at the very least this trial can ascertain the truth, acknowledge facts, provide a sense of tranquility for victims and bring closure to their process of grieving."

\section{Time, Justice, and Healing}

Can justice bring such closure to people like Vann Nath after so much time has passed? There is little doubt that the path to something like "closure" or "reconciliation" is a deeply personal one, inflected by one's past suffering, subsequent experiences, worldview, and sense of the future. It is not a certain course and has many pathways. 
One of the difficulties about transitional justice initiatives like the KRT is that they promise too much. Promises abound that the truth will be revealed as victims supposedly attain a sense of peace, justice, reconciliation, healing, and closure. Such sweeping proclamations are bound to fail. Yet they appear again and again in trials and truth commissions and thereby set up the mechanisms for failure.

There are many reasons that transitional justice practitioners and personnel make such promises. For example, they play well to the donors who enable the mechanisms. But they are also the stuff of what I have called a "transitional justice imaginary," ${ }^{32}$ or a set of interrelated discourses, practices, and institutional forms that help generate a sense of shared belonging among a group of people - in this case, members of the transitional justice community or larger international community.

This imaginary, while not monolithic, can nevertheless be found in a variety of transitional justice contexts. It has at least four key dimensions. The transitional justice imaginary is: normative (linked to certain truth claims and moral assumptions); performative (an imagined community is constituted through enactment); and productive (it produces certain subject positions). It is also characterized by a temporality premised on linear intervals (a pre and a post-state), an orientation (war and peace), and a teleology (a straightforward movement between these two intervals or states). In particular, this "transitional justice time"33 implicitly parses societies into a pre-state of conflict and a post-state of liberal democracy, along with a related set of binaries (violent/peaceful, chaotic/ordererly, barbarism/civilization, primitive/sophisticated, irrational/ rational, traumatic/healthy, and so forth). To effect this transition, history is shrunk and erased, filtering out the grey zones that disrupt this teleological narrative of past and future.

The temporal jurisdiction of the KRT highlights this point, as complicated pasts are backgrounded even as truth claims are made. This temporal foreshortening is paradoxical, for, according to its own logic, truth is required for closure yet the temporal modality of transitional justice is one of shrinkage and thus a truncated history. In the end, such insights ask us to critically reflect upon the presuppositions of transitional justice and ask what sorts of truths are produced and for what reasons. From the vantage of this "critical transitional justice studies" perspective, ${ }^{34}$ one can see how time is manipulated to assert an imaginary that casts the post-conflict society into a subordinate position even as it asserts a teleology of movement toward a liberal democratic end.

One of the key dangers of this transitional justice imaginary is that it directs attention away from social practice and the ways in which the meaning and understanding of such transitional justice processes are negotiated on the ground. As opposed to attaining some sort of unilineal sense of closure or healing from the tribunal, people like Vann Nath grapple with the past in different ways through their life-course.

In his 1998 memoir, A Cambodian Prison Portrait: One Year in the Khmer Rouge's S-21, Vann Nath recalls meeting Him Huy, one of his former captors at S-21, in 1996. He experienced a range of emotions, including anger, before coming to pity Huy. During the Khmer Rouge period, this man was like "a savage bull, a lion. None of the prisoners, including myself, had dared to look him in the face then. Now, he was in a deadlock, with no more fangs or horns. Seeing him in this situation, somehow I felt pity for him."35

When Pol Pot, the leader of the Khmer Rouge, died two years later, Vann Nath was once again "flooded with a jumble of confused thoughts and emotions." ${ }^{36}$ On the one hand, he felt relieved because "the bloodiest master criminal had disappeared forever from this world." On the other hand, he felt sorrow that "I would never fulfill my long-held desire to see Pol Pot standing in the dock, facing a court to answer for his crimes."37

In the end, however, Vann Nath viewed the death of Pol Pot and other leaders who died without being tried through a Buddhist frame. His book concludes, "I believe there will be justice. A person harvests what he has sown. According to the Buddhist religion, good actions produce good results, bad actions produce bad results. The peasant harvests the rice, the fisherman catches the fish. Pol Pot and his henchmen will harvest the actions they committed. They will reap what they have sown."38

Here we encounter yet another form of temporality, what we might call "vernacular time." Vernacular time refers to the specific local understandings and temporal practices operative in a given locality. In this case, Vann Nath notes a particular Buddhist vernacular conception of time that is frequently evoked, through speech as well as through non-verbal and ritual acts, in Cambodia. From this Buddhist perspective, our being is constituted and reconstituted in a cyclical fashion. On a cosmic level, the universe is created and then degrades before being renewed. Ontologically, the Buddhist doctrine of samsara holds that being is fleeting, a momentary coalescence of constitutive elements. Each moment of coalescence is conditioned by what preceded it, a notion that is reflected in the doctrine of karma ( $k a m m a)$ that Vann Nath invoked in the passage above. Those who do good will receive good; those who do bad deeds will suffer the consequences. A form of cosmic justice is at work here, as punishment for bad deeds is an inevitable part of being. 
This Buddhist vernacular of time, of course, stands at odds with the linearity and progressive teleology of juridical time and related conceptions in the transitional justice imaginary, which asserts a binary of trauma / ill-health as well as health / closure that is overcome through the tribunal. For if there are other ways of achieving closure, such as through Buddhist ritual belief and practices centered around the notion of meritous and demeritous action, one of the key justifications of the ECCC would be undermined. A similar argument could be made about related notions of Buddhist forgiving and forgetting. A more modest, yet powerful way of approaching time and healing would embrace an openness to different ways of coping with and dealing with the past, ranging from religious understanding to juridical mechanisms.

We can glimpse some of the ways in which Vann Nath sought his path forward. Buddhism was one of the cornerstones of his understanding of the world, a set of beliefs and practices that had taken shape in his youth while studying at a pagoda. ${ }^{39}$ It provided him with a way to cope with his past suffering and to approach his future experiences, such as his encounter with Him Huy and his response to Pol Pot's death.

Art also seemed to provide Vann Nath with a way of grappling with the past, at first by painting images from S-21 and then later participating in painting workshops with young students. ${ }^{40}$ This engagement with the younger generation was very important to Vann Nath. He chose not to become a civil party, foregoing a form of participation centered on rights for one that was more humanistically oriented (though clearly civil parties have a variety of motives for their participation, including humanistic ones) ${ }^{41} \mathrm{He}$ did this in part because of health concerns but also because he did not want to assert a primacy over other survivors. He also did not want reparations, perhaps because he felt nothing could compensate for his suffering. ${ }^{42}$

When asked why he still wanted to testify, Vann Nath stated that, ever since he was detained at S-21, he "determined that if one day I survived, [...] I would compile the events to reflect on what happened so that the younger generation would know [...] So I had to reveal, I had to write, I had to compile, and it can [serve] as a mirror to the younger generation of the lives of those who were accused with no reason, who committed no wrong [...] I do not want anything more than that" and a sense of justice. ${ }^{43}$ Here also we find an interesting conjunction of vernacular and transitional justice time, as the Buddhist emphasis on clear understanding dovetails with juridical notions of truth and evidence.

Did Vann Nath achieve this sense of justice after the Duch trial and upon seeing the surviving senior leaders of the Khmer Rouge stand trial on the first day of the initial hearing? It is impossible to know for certain, though, even if he felt some ambivalence, overall he seemed to have a positive attitude toward the court, as he indicated to me that day we attended the opening of Case 002. He also seemed pleased in some ways by the initial Duch verdict (he did not live long enough to see Duch's final sentence of life imprisonment), as illustrated by the fact that he participated in verdict distributions organized by the ECCC's Public Affairs office.

But through his paintings, public statements about the past, Buddhist practices and beliefs, engagement with the younger generation, testimony during the Duch trial, participation in court outreach events, and other activities, Vann Nath seems to have moved closer to something like healing and closure to the extent to which it can ever be attained by a survivor.

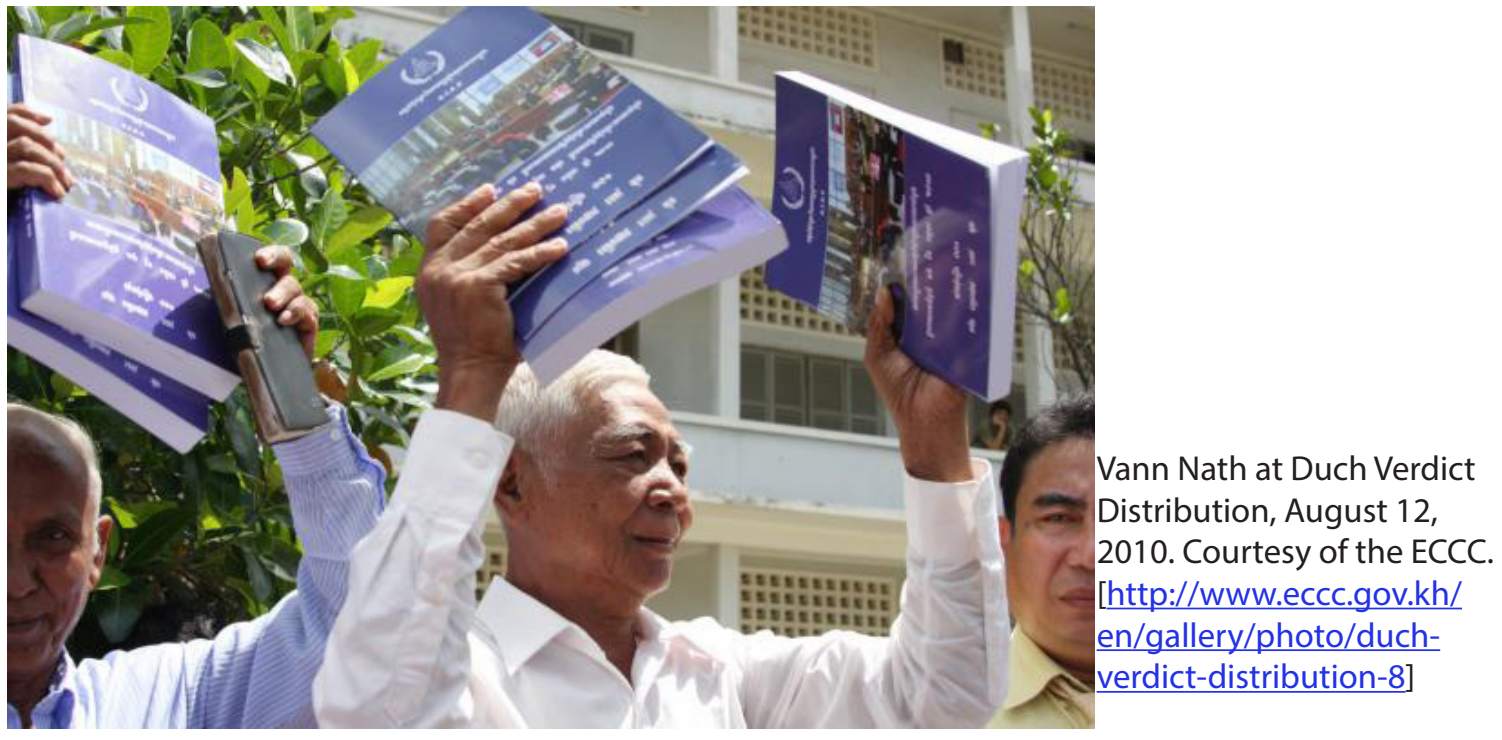


Before he died, Vann Nath completed one last painting. It depicts Duch sitting between two columns of skulls and bones that recede into the distance of a gloomy horizon. Vultures circle in the sky above, perhaps a Buddhist symbol of the attachment and craving that drive people to sin. Before Duch, who gazes mournfully into the distance, lies a copy of the verdict from his trial.

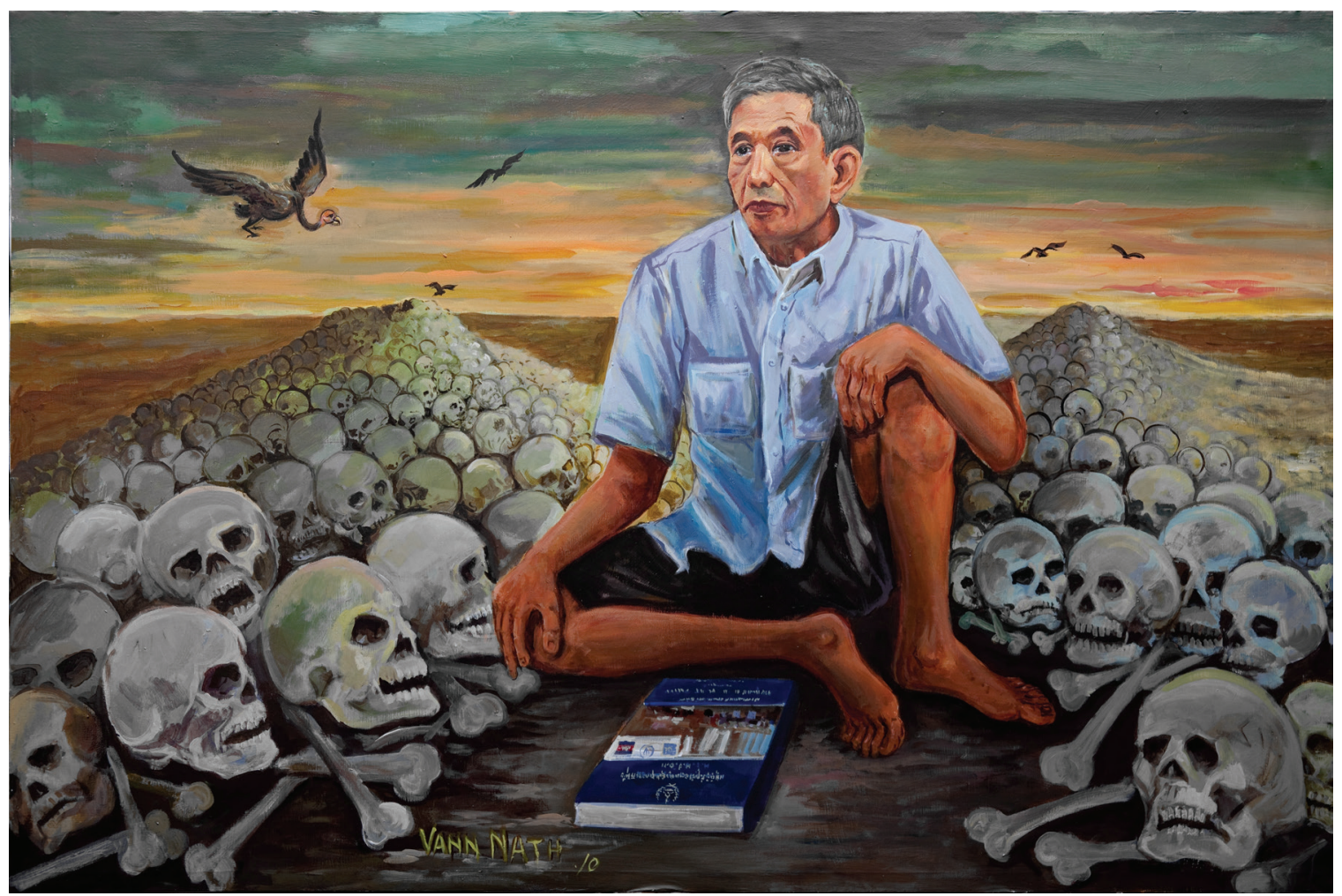

Duch verdict. Painting by Vann Nath. Photo courtesy of the Documentation Center of Cambodia. Permission courtesy of Kith Eng (Vann Nath's wife).

This new painting seems familiar. After gazing at it for a while, it appears that Vann Nath may have modeled the painting on his own S-21 self-portrait. Both figures assume the same posture with the same dejected expression. The two walls of the S-21 cell have been replaced with the two columns of skulls. Instead of the iron shackles in the S-21 portrait, in the new painting Duch is "bound" by the verdict, which sentences him to imprisonment. But the new painting is also a Buddhist one, suggesting that, like a shadow, the deeds of Duch's past trail behind him, conditioning his future. It suggests how time and justice were interlinked for Vann Nath, a fusion of juridical and Buddhist time in which Duch was now imprisoned for his bad deeds in the Khmer Rouge past, one from which Vann Nath had at last been released.

\section{End Notes}

1. Since 2009, the author has been conducting research, ranging from on-site observations to participant-observation to semistructured interviews, on the Khmer Rouge Tribunal. This research was supported by grants from the United States Institute of Peace and Rutgers Research Council and a 2011-12 fellowship from the Institute for Advanced Study in Princeton. I'd like to thank the reviewers of this essay, the journal editors, Rafiki Ubaldo, Laura Cohen, and Nicole Cooley for their helpful suggestions on this essay.

2. Trial Chamber, Extraordinary Chambers in the Courts of Cambodia, "Transcript of Initial Hearing - Nuon Chea, Ieng Sary, Ieng Thirith, Khieu Samphan Public," June 28, 2011, p. 3. (Hereafter “Transcript of Initial Hearing - Day 2”).

3. Trial Chamber, Extraordinary Chambers in the Courts of Cambodia, "Transcript of Initial Hearing - Nuon Chea, Ieng Sary, Ieng Thirith, Khieu Samphan Public," June 27, 2011, p. 14. (Hereafter “Transcript of Initial Hearing - Day 1”).

4. Vann Nath, A Cambodian Prison Portrait: One Year in the Khmer Rouge's S-21 (Bankok: White Lotus, 1998), p. 113. (Hereafter, "A Cambodian Prison Portrait"). 
5. Trial Chamber, Extraordinary Chambers in the Courts of Cambodia, "Transcript of Trial Proceedings - Kaing Guek Eav 'Duch' Public," Trial Day 35, June 29, 2009, p. 55-6. (Hereafter "Vann Nath Testimony"). See also "A Cambodian Prison Portrait."

6. Miranda Letisinger, "First ex-Khmer Rouge Member faces Genocide Court," CNN, February 16, 2009 (http://edition.cnn. com/2009/WORLD/asiapcf/02/16/cambodia.genocide/index.html, accessed December 13, 2011).

7. "Vann Nath Testimony," p. 64.

8. Ibid, p. 23.

9. Ibid., p. 68 .

10. Youk Chhang, "Vann Nath: A Witness to History (S-21 Survivor Passed Away)," Documentation Center of Cambodia, September 5, 2011 (http://www.d.dccam.org/Projects/Living Doc/Photos/2011/S-21 Survivor Passed Away/index.html, accessed December 13, 2011; hereafter "Vann Nath: A Witness"). See also T. Rees Shapiro, "Vann Nath, whose artistry allowed him to survive Cambodian prison, dies," Washington Post, September 6, 2011 (http://www.washingtonpost.com/local/ obituaries/vann-nath-whose-artistry-allowed-him-to-survive-cambodian-prison-dies/2011/09/06/gIQARPhA8J story. html, accessed December 6, 2011)

11. Kong Sothanarith, "Tribunal Parties Want Faster Prosecution at UN Court," VOA Khmer, September 7, 2011 (http://www. voanews.com/khmer-english/news/Tribunal-Parties-Want-Faster-Prosecution-at-UN-Court-129378318.html, accessed December 13, 2011). See also Bridget Di Certo, "Health Woes Slow KRT," Phnom Penh Post, December 8, 2011 (http://www. phnompenhpost.com/index.php/2011120853239/National-news/health-woes-slow-krt.html, accessed December 13, 2011).

12. Ieng Sary Defense Team, Extraordinary Chambers in the Courts of Cambodia, "Ieng Sary's Notice to the Trial Chamber that he will not testify during Trial” October 24, 2011 (http://www.eccc.gov.kh/sites/default/files/documents/courtdoc/E101_4 EN.PDF, accessed December 6, 2011).

13. Trial Chamber, Extraordinary Chambers in the Courts of Cambodia, "Trial Chamber Decision on Ieng Thirith's Fitness to Stand Trial," November 17, 2011 (http://www.eccc.gov.kh/en/articles/trial-chamber-decision-ieng-thirith's-fitness-standtrial, accessed December 6, 2011).

14. Trial Chamber, Extraordinary Chambers in the Courts of Cambodia, September 22, 2011 (http://www.eccc.gov.kh/en/ document/court/severance-order-pursuant-internal-rule-89ter, accessed December 6, 2011).

15. “Transcript of Initial Hearing - Day 1,” p. 11, 13.

16. Ibid., p. 15.

17. Ibid., p. 16.

18. Ibid., p. 14.

19. Ibid., p. 16.

20. See, for example, United Nations, "Report of the Group of Experts for Cambodia established pursuant to General Assembly Resolution 52/135," February 18, 1999 (http://unakrt-online.org/Docs/GA\%20Documents/1999\%20Experts\%20Report.pdf, accessed December 20, 2011).

21. Ibid., II.5.

22. Agreement between the United Nations and the Royal Government of Cambodia concerning the Prosecution under Cambodian Law of Crimes Committed during the period of Democratic Kampuchea," June 6, 2003 (http://www.eccc.gov. kh/sites/default/files/legal-documents/Agreement between UN and RGC.pdf, accessed December 20, 2011). See also Tom Fawthrop and Helen Jarvis, Getting Away with Genocide: Elusive Justice and the Khmer Rouge Tribunal. London: Pluto, 2004.

23. “Transcript of Initial Hearing - Day 1,” p. 109.

24. “Transcript of Initial Hearing - Day 2," p., 3.

25. Ibid., p. 82.

26. Author fieldnotes, Press Conference, Extraordinary Chambers in the Courts of Cambodia, Phnom Penh: Cambodia, June 30, 2011. See also: http://vimeo.com/26064118, accessed December 20, 2011.

27. “Transcript of Initial Hearing - Day 2," p. 59f.

28. Ibid., p. 69-70.

29. Ibid., p. 71.

30. Ibid., p. 75.

31. “Transcript of Initial Hearing - Day 1," p. 115-16.

32. "The Transitional Justice Imaginary: Uncle San, Aunty Yan and Victim Participation at the Khmer Rouge Tribunal." In Justice for Victims: Perspectives on Rights, Transition, and Reconciliation. Inge Vanfraechme, Antony Pemberton, and Felix Mukwiza Ndahinda, eds., p. 247-261. New York: Routledge Press, 2014. (hereafter “Transitional Justice Imaginary").

33. Alexander Laban Hinton, “Transitional Justice Time: Uncle San, Aunty Yan, and the Khmer Rouge Tribunal." In Genocide and Mass Atrocities in Asia: Legacies and Prevention. Deborah Mayerson and Annie Pohlman, eds. p. 86-98, New York: Routledge, 2013. [http://www.ncas.rutgers.edu/select-recent-publications] 
34. Alexander Laban Hinton, ed., "Introduction: Toward an Anthropology of Transitional Justice." In Transitional Justice: Global Mechanisms and Local Realities after Genocide and Mass Violence, Alexander Laban Hinton, ed., p. 1-24, New Brunswick: Rutgers University Press, 2010.

35. Vann Nath, "A Cambodian Prison Portrait," p. 113.

36. Ibid., p. 116.

37. Ibid., p. 117.

38. Ibid., p. 118.

39. Rithy Panh's homage to Vann Nath after his death, "Allocution de Rithy Panh," September 14, 2011, e-mail from Association le Cercle des Amis de Vann Nath (hereafter "Rithy Panh homage to Vann Nath").

40. Vann Nath's paintings can be found at many sites on the internet. See, for example, the webpage devoted to Vann Nath at "Vann Nath - Paint Propaganda or Die -- The Art History Archive" (http://www.arthistoryarchive.com/arthistory/asian/ Vann-Nath.html, accessed July 5, 2012).

41. On this point, see also Youk Chhang, "Vann Nath: A Witness."

42. Vann Nath Testimony, p. 103. See also "Rithy Panh's homage to Vann Nat."

43. "Vann Nath Testimony," p. 54-55. 